\title{
AIDS-Related Kaposi Sarcoma I1 (Poor Risk)
}

National Cancer Institute

\section{Source}

National Cancer Institute. AIDS-Related Kaposi Sarcoma I1 (Poor Risk). NCI Thesaurus.

Code C134980.

AIDS-related Kaposi sarcoma in which the CD4 cell count is lower than 150 cells per cubic $\mathrm{mm}$. 